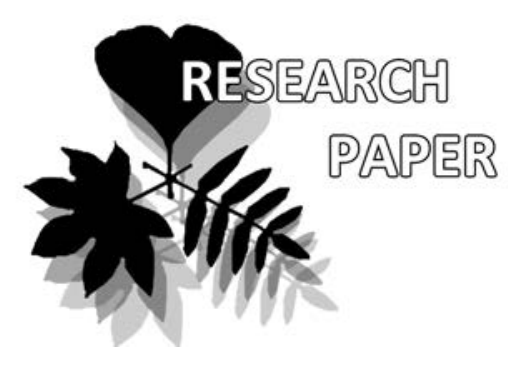

\title{
Wood anatomy of Brabejum and Macadamia (Macadamiinae, Proteaceae)
}

\author{
Anna V. Stepanova ${ }^{1,2 *}$ \& Alexei A. Oskolski ${ }^{1,2}$
}

AnnaV. Stepanova ${ }^{1,2 *}$

e-mail: stepanovabot@gmail.com

Alexei A. Oskolski ${ }^{1,2}$

e-mail: aoskolski@gmail.com

${ }^{1}$ Department of Botany and Plant Biotechnology, University of Johannesburg, Johannesburg, South Africa

${ }^{2}$ Komarov Botanical Institute RAS, Saint-Petersburg, Russia

* corresponding author

Manuscript received: 21.05.2019

Review completed: 17.07.2019

Accepted for publication: 22.08.2019

Published online: 30.08.2019

\begin{abstract}
A B S T R A C T
Wood structure of Brabejum stellatifolium and Macadamia integrifolia (subtribe Macadamiinae, tribe Macadamieae, Proteaceae) is described for the first time. These species share exclusively simple perforation plates, minute to small alternate intervessel pits, non-septate libriform fibers, banded and unilaterally paratracheal axial parenchyma, and the rays of two distinct sizes, i.e. the suite of typical wood traits for many of Proteaceae. Our observations together with reported data suggest that the lineage comprising Brabejum, Macadamia and Panopsis is distinctive from closely related members of the tribe Macadamieae by the occurrence of vasicentric tracheids combined with the lack of fiber tracheids. More abundant axial parenchyma in Macadamia and Panopsis than in Brabejum is seemingly consistent with the global tendency to increase of amount of this tissue in the regions with warm climate. Libriform fibers is Macadamia integrifolia show one of the highest degrees of intrusiveness $(\mathrm{F} / \mathrm{V}$ ratio $=3.98)$ reported within Proteaceae to date.
\end{abstract}

K e y w o r d s : Brabejum, Macadamia, Proteaceae, wood anatomy, vasicentric tracheids

\section{P E 3 Ю M E}

Степанова А.В., Оскольский А.А. Анатомия Аревесины Brabejum и Macadamia (Macadamiinae, Proteaceae). Впервые описано анатомическое строение Аревесины Brabejum stellatifolium и Macadamia integrifolia (подтриба Macadamiinae, триба Macadamieae, семейство Proteaceae). А^я этих видов характерен набор признаков, типичных м^я многих протейных, таких как исключительно простые перфорационные пластинки, очень мелкие поры межсосудистой поровости, несептированные Аревесинные волокна, аксиальная паренхима односторонне-паратрахеальная и в тангентальных полосах, Аве отчетливых размерных группы кучей. Наши и китературные Аанные указывают на то, что монофиметическая группа, вкАючающая роды Brabejum, Macadamia и Panopsis, отличается от Аругих представителей Macadamieaе наличием вазицентрических трахеил в сочетании с отсутствие волокнистых трахеил. Более обильная аксиальная паренхима у Macadamia и Panopsis по сравнению с Brabejum соответствует глобальной тенденции к увеличению количества этой ткани у растений в регионах с тёплым кАиматом. Аревесинные волокна Macadamia integrifolia характеризуются одним из самых высоких уровней интрузивности (отношение среАней Алины волокон к среАней Алине члеников сосудов равно 3,98), известным Аля протейных.

КАючевые слова: Brabejum, Macadamia, Proteaceae, анатомия древесины, вазицентрические трахеиды
Subtribe Macadamiinae L.A.S. Johnson \& B.G. Briggs belonging to the tribe Macadamieae C. Venkata Rao of Weston \& Barker's (2006) classification of Proteaceae Juss. comprises five genera with 36 species of evergreen trees and shrubs with mostly verticillate leathery leaves (Weston 2007). This small lineage is widespread across the southern hemisphere. The best known genus of this group is Macadamia F. Muell. with four species which are naturally distributed in subtropical regions of eastern Australia, two of which ( $M$. integrifolia Maiden \& Betche and M. tetraphylla L.A.S. Johnson and their hybrids) are widely cultivated for their edible seeds (macadamia nuts). The genus Lasjia P.H. Weston \& A.R. Mast, that has recently been separated from Macadmia (Mast et al. 2008), comprises four tropical species from tropical rain forests of north-eastern Queens- land and one species from Sulawesi. Monospecific Nothorites P.H. Weston, that has initially been described as a species of Orites R. Br. from the tribe Roupaleae (George \& Hyland 1995), is also endemic of north-eastern Queensland. Unlike these three genera, 25 species of Panopsis Salisb. are widespread in shrublands, savannas, xerophytic woodlands, riparian forests and lowland to montane rainforests of tropical South and Central America (Prance et al. 2007, Weston 2007). Finally, Brabejum stellatifolium L., the only species of the genus Brabejum L., is a component of fynbos biome and Afrotemperate forests restricted to the Cape region in South Africa with its Mediterranean climate (Mucina \& Rutherford 2006, Weston 2007, Mast et al. 2008).

The time of radiation of the subtribe Macadamiinae is estimated as the late Oligocene - early Miocene. Disjunct 
distribution of this group is seemingly a result of long-distance dispersal of their buoyant diaspores from Australia to South America and Africa by the Antarctic Circumpolar Current that has also developed in the Oligocene. The evolutionary shifts from the early fruit and seed maturity found in Macadamia and other Australian members of this group to the tardy dehiscence at the seed germination, which is shared by extra-Australian taxa are well consistent with this scenario (Mast et al. 2008).

The subtribe Macadamiinae is poorly explored by wood anatomists: the detailed information on wood structure has been published to date only for two species of Panopsis (Mennega 1966, Detienne \& Jacquet 1983). Brief wood anatomical description and microphotos are available also for Macadamia ternifolia F. Muell. (Chattaway 1948, InsideWood 2004-onwards). Quantitative data on wood density, diameter of vessel lumina and vessel wall thickness in the Brabejum wood have been reported by Crous et al. (2012). The aim of the current study is the detailed examination of wood structure of Brabejum and Macadamia, and its comparisons with related groups of Proteaceae.

\section{MATERIALAND METHODS}

Wood sample of Brabejum stellatifolium was collected by Alexei Oskolski on 05.09.2016 in afrotemperate forest on the eastern slope of Table Mountain near the Kirstenbosch Botanical Garden, Cape Town, South Africa. Wood sample of Macadamia integrifolia was taken by him on 10.04.2019 from the tree cultivated in Pretoria, South Africa. Both wood samples were collected from large branches. Herbarium vouchers (A.A. Oskolski \# 98 for B. stellatifolium and \# 281 for M. integrifolia) are deposited in JRAU; wood samples are deposited in the Xylarium of the Komarov Botanical Institute, St. Petersburg, Russia (LEw).

Transverse, radial, and tangential microtome sections of $20-30 \mu \mathrm{m}$ in thickness were stained with alcian blue/safranin (Jansen et al. 2004), dehydrated in gradient series of alcohol, and then mounted in Euparal. Macerations were made using Jeffrey's solution (Johansen 1940). Descriptive terminology followed the recommendations of the IAWA Committee (1989). The quantitative data are summarized in Table 1. Details of the microstructure of intervessel pits were investigated by scanning electron microscopy (SEM TESCAN, soft - VegaTS) at Spectrum, University of Johannesburg. For the SEM examination, dried wood samples were mounted on aluminum stubs with double-sided carbon tape and coated with gold.

Evolution of selected wood anatomical features was clarified by mapping discrete characters on a subsample of the tree recovered from the Bayesian analyses of a data set of three chloroplast DNA and four nuclear DNA sequences as well as morphological data for the tribe Macadamieae (Mast et al. 2008). Character optimization along the branches of the tree was illustrated using the parsimony reconstruction method of the Character History Tracing option in the computer package Mesquite 2.75 (Maddison \& Maddison 2011).

\section{RES U LT S}

\section{Wood anatomy of Brabejum stellatifolium (AO 98-16)}

Wood diffuse-porous. Growth ring boundaries indistinctly marked by 3-6 rows of weakly flattened fibres. Vessels few (up to 25 per $\mathrm{mm}^{2}$ ), medium to wide $(67-178 \mu \mathrm{m}$ in tangential diameter), solitary, in clusters and in tangential multiples of 2-8 (up to 12), thin-walled (wall thickness 2.8-5.3 $\mu \mathrm{m}$ ) (Fig. 1a). Vessel lumina round to slightly angular. Vessel elements relatively long (average length $710 \mu \mathrm{m}$, range 299-987). Perforation plates simple. Intervessel pits alternate, minute to small (3.1-5.9 $\mu \mathrm{m}$ in vertical size), non-vestured, with oblique oval apertures (Fig. 1b,c). Vessel-ray pits distinctly bordered (occasionally with reduced borders or simple), similar to intervessel pits in size and shape. Solitary vasicentric tracheids occur in vessel groups. Helical thickenings not found.

Fibres libriform, non-septate, long (fiber length 1082-2056 $\mu \mathrm{m}$ ), with moderate intrusiveness $(\mathrm{F} / \mathrm{V}$ ratio $=2.3)$, with simple to minutely bordered pits on very thin walls $(2.8-3.7 \mu \mathrm{m}$ thick $)$. 


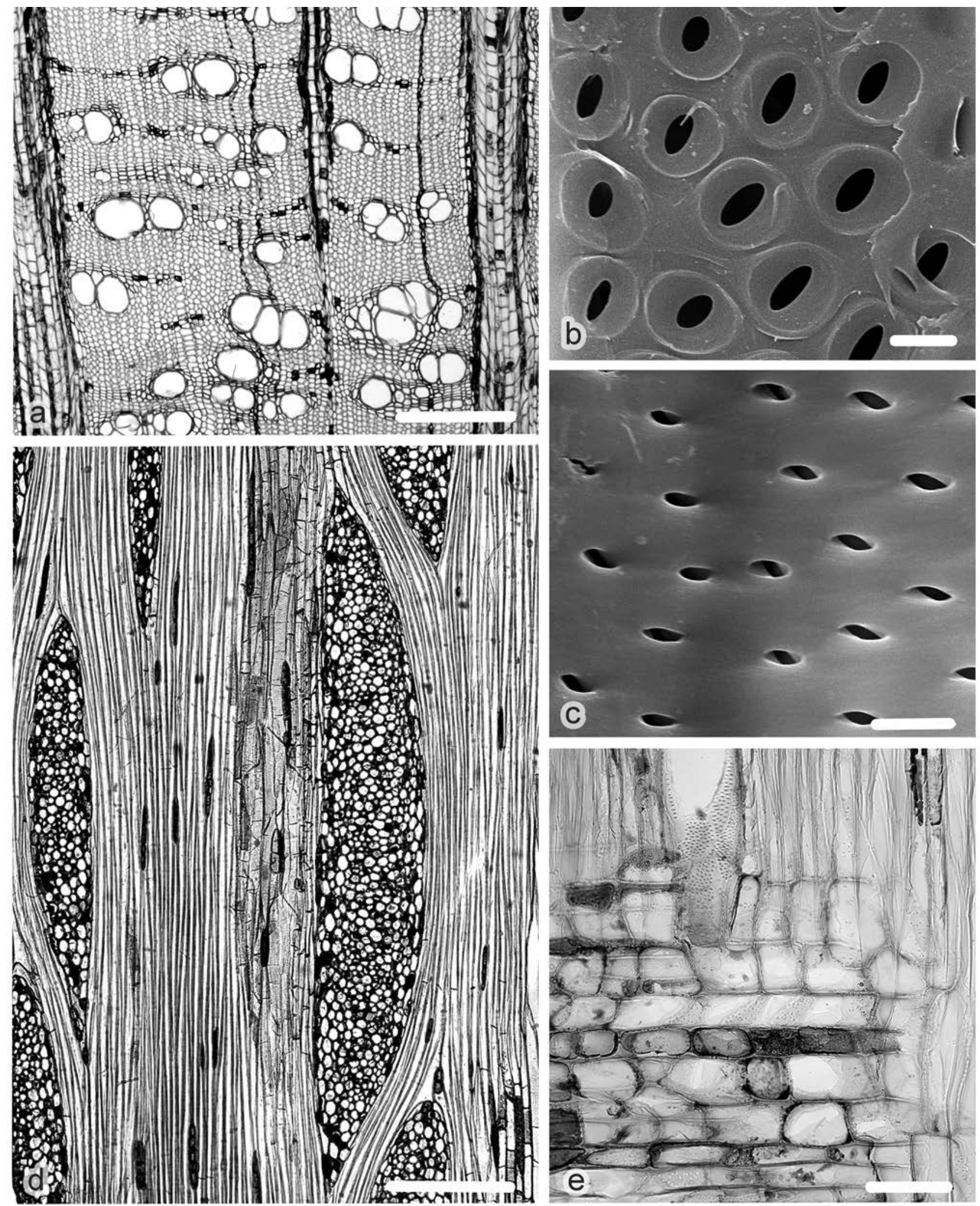

Figure 1 Wood structure of Brabejum stellatifolium L. [AO 98-16]: (a) vessels in short tangential multiples and clusters, thin-walled libriform fibres, axial parenchyma unilateral paratracheal and in 1-3-seriate tangential line, light microscopy (LM), transverse section (TS); (b) alternate intervessel pits with chambers lacking warty layer (SEM, RLS); (c) apertures of intervessel pits without groove-like wall sculptures, scanning electron microscopy (SEM), radial longitudinal section (RLS); (d) rays of two distinct sizes (uniseriate and 8-15-seriate ones), strands of axial parenchyma (LM, TLS); (e) procumbent, square and upright ray cells, vessel-ray pits (LM, RLS). Scale bars $=500 \mu \mathrm{m}(\mathrm{a}, \mathrm{d}), 100 \mu \mathrm{m}(\mathrm{e}), 5 \mu \mathrm{m}(\mathrm{b}, \mathrm{c})$

Axial parenchyma unilateral paratracheal, winged aliform and banded (Fig. 1a), in lines and narrow (up to 5-seriate) bands associated with vessels and vessel groups in unilateral pattern (i.e. vessels and vessel groups mostly attached to axial paren- chyma bands with their outer sides, but occasionally embedded into the bands). Axial parenchyma strands consist of 2-6 cells.

Rays few (1.1-3.2 per $\mathrm{mm}$ ), of two distinct sizes (Fig. 1d). Narrow rays uniseriate (occasionally 2-seriate), 


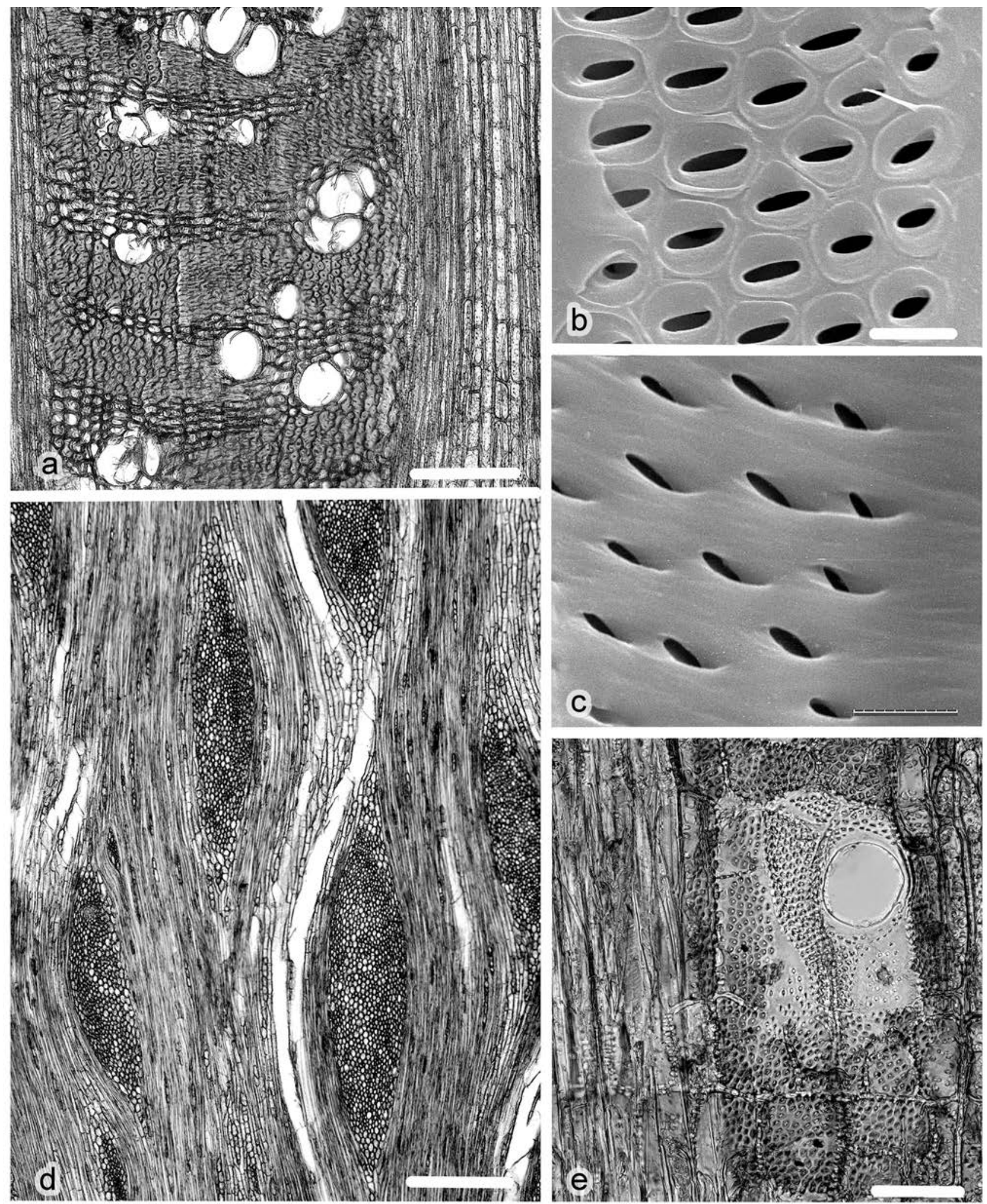

Figure 2 Wood structure of Macadamia integrifolia Maiden \& Betche [AO281-19]: (a) vessels solitary and in clusters, thick-walled libriform fibres, 3-7-seriate bands of axial parenchyma in reticulate arrangement (LM, TS); (b) chambers of intervessel pits lacking warty layer (SEM, RLS); (c) apertures of alternate intervessel pits surrounded and occasionally interconnected by groove-like wall sculptures (SEM, RLS); (d) rays of two distinct sizes (1-2-seriate and 5-25-seriate ones) (LM, TLS); (e) simple perforation plates, band of axial parenchyma, mostly procumbent ray cells (LM, RLS). Scale bars $=500 \mu \mathrm{m}(\mathrm{a}), 200 \mu \mathrm{m}(\mathrm{d}), 50 \mu \mathrm{m}(\mathrm{e}), 5 \mu \mathrm{m}(\mathrm{b}, \mathrm{c})$

consists mostly of square and upright cells, occasionally also with procumbent cells. Broad rays 7-20 seriate, up to $2.9 \mathrm{~mm}$ in height, composed mostly of procumbent cells, with upright and square cells in 1-3 marginal rows and in incomplete sheaths (Fig. 1e). No sclerified ray cells found.
Brown content occur in axial parenchyma and ray cells. Crystals and silica bodies not found.

Note: Crous et al. (2012) reported much smaller diameter of vessel lumina in Brabejum stellatifolium (average 39.6$42.5 \mu \mathrm{m})$ than we found in this species. 


\section{Wood anatomy of}

\section{Macadamia integrifolia (AO 281-19)}

Wood diffuse-porous. Growth rings absent. Vessels not numerous (up to 30 per $\mathrm{mm}^{2}$ ), moderately wide (25$100 \mu \mathrm{m}$ in tangential diameter), solitary and mostly in small clusters and tangential multiples of 2-4 (up to 8) vessels associated with tangential bands of axial parenchyma, thinwalled (wall thickness 2.9-5.6 $\mu \mathrm{m}$ ) (Fig. 2a). Vessel lumina round to slightly angular. Vessel elements relatively short (average length $376 \mu \mathrm{m}$, range $200-520 \mu \mathrm{m}$ ). Perforation plates simple. Intervessel pits alternate, minute to small (3.4-5.0 $\mu \mathrm{m}$ in vertical size), non-vestured (Fig. 2b), with oblique to horizontal oval apertures, sometimes interconnected by shallow grooves (Fig. 2c). Vessel-ray pits distinctly bordered (occasionally with reduced borders or simple), similar to intervessel pits in size and shape. Solitary vasicentric tracheids occur in vessel groups. Helical thickenings not found.

Fibres libriform, non-septate, long (1000-1900 $\mu \mathrm{m}$ in length), with high intrusiveness $(\mathrm{F} / \mathrm{V}$ ratio $=3.98)$, with simple to minutely bordered pits on thick to very thickwalled (3.8-10.5 $\mu \mathrm{m})$.

Axial parenchyma (Fig. 2a) abundant in 3-7-seriate tangential bands associated with vessels and vessel groups in unilateral paratracheal pattern (i.e. vessels and vessel groups mostly attached to axial parenchyma bands with their outer sides, but occasionally embedded into the bands). Axial parenchyma strands consist of 2-6 cells.

Rays of two distinct sizes (Fig. 2d). Narrow rays uniseriate (occasionally $2-3$-seriate), consists mostly of square and upright cells, occasionally also with procumbent cells. Broad rays 7-34-seriate, up to $2.9 \mathrm{~mm}$ in height, composed mostly of procumbent cells, with upright and square cells in 1-3 marginal rows (Fig. 2e) and in incomplete sheaths. No sclerified ray cells found. Brown content occur in axial parenchyma and ray cells. Crystals and silica bodies not found.

\section{Character evolution within the Macadamieae}

Analysis of wood trait evolution based on results of our observations together with other available anatomical data (Chattaway 1948, Mennega 1966, Kribs 1968, Detienne \& Jacquet 1983, Sosef et al. 1998, InsideWood 2004-onwards) showed that the patterns of variation in two wood features, namely the occurrence of distinctly bordered pits on fiber walls (Fig. 3a) and the presence of vasicentric tracheids (Fig. 3b) are apparently consistent with the topology of the phylogenetic tree of the tribe Macadamieae (Mast et al. 2008). Although no clear tendencies in evolution of these traits were revealed, the character mapping suggested that the loss of bordered pits on fiber walls as well as the gain of vasicentric tracheids (Fig. 3a,b) are associated with diversification of the subtribe Macadamiineae.

\section{DISCUSSION}

Our observations together with the wood anatomical data reported for two species of Panopsis (Mennega 1966, InsideWood 2004-onwards) suggest that three genera of the subtribe Macadamiinae share exclusively simple perforation plates, minute to small alternate intervessel pits, non-septate libriform fibers, banded and unilaterally para-
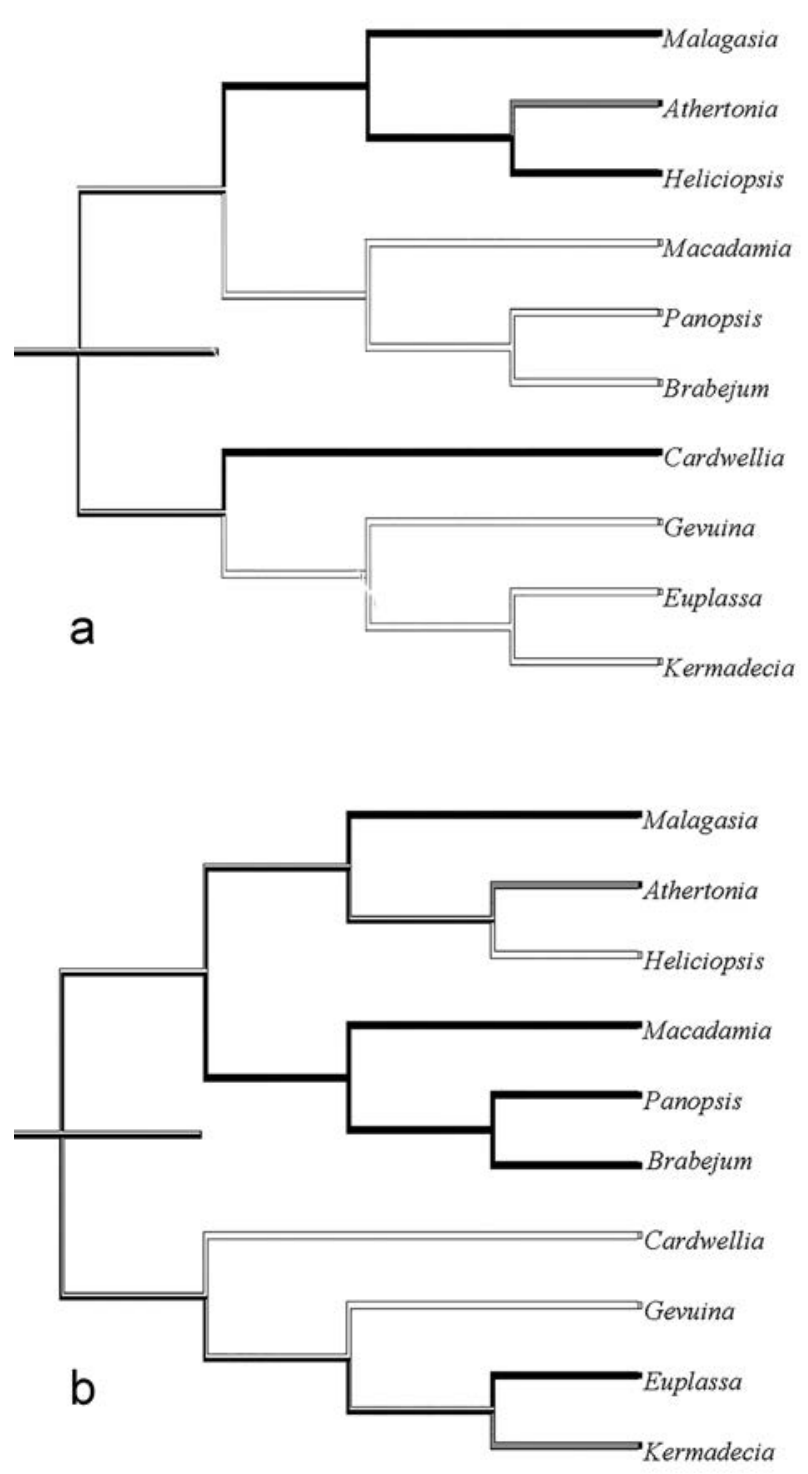

Figure 3 Distribution of the wood character states within the Macadamieae mapped onto a subsample of phylogenetic tree, recovered from the Bayesian analyses of a data set of three chloroplast DNA, four nuclear DNA sequences and morphological data (Mast et al., 2008). (A) the presence of distinctly bordered pits on fiber walls (white-absent, black-present, gray - unknown); (B) the presence of vasicentric tracheids (white - absent, black present, gray - unknown)

tracheal axial parenchyma, and the rays of two distinct sizes (mostly uniseriate rays combined with $>6$-seriate ones). This suite of traits is typical for many other genera of Proteaceae (Chattaway 1948, Metcalfe \& Chalk 1950, InsideWood 2004-onwards). The lineage comprising Brabejum, Macadamia and Panopsis is distinctive, however, from closely related members of the tribe Macadamieae by the combination of the occurrence of vasicentric tracheids and the lack of fiber tracheids, i.e. the fibers with distinctly bordered pits on their walls.

Both these traits are variable within Proteaceae, and even within Macadamieae. The presence of bordered pits on fiber walls has been reported in Placospermum C.T. White \& W.D. Francis (Lanyon 1979) and Persoonia Michx. (Patel 1982) belonging to the subfamily Persoonioideae, Dilobeia 
Thouars and Faurea Harv. (InsideWood 2004-onwards) of the subfamily Proteoideae as well as in several lineages of the subfamily Grevilleoideae, i.e. in Helicia Pers. (Sosef et al. 1998) of the tribe Roupaleae, in Lomatia R. Br. (Tortorelli 1956), Stenocarpus R. Br. (Chattaway 1948, InsideWood 2004-onwards), and Embothrium J.R. Forst. \& G. Forst. (Detienne \& Jacquet 1983) of the tribe Embothrieae, in Cardwellia F. Muell. (Kribs 1968), Heliciopsis Sleumer (Sosef et al. 1998), Euplassa Salisb. (Detienne \& Jacquet 1983) and Malagasia L.A.S. Johnson \& B.G. Briggs (InsideWood 2004-onwards) belonging to the tribe Macadamieae, and in Knightia R. Br., the genus insertae sedis, as well (Patel 1982). Within Macadamieae, the loss of fiber tracheids is synapomorphic for the subtribe Macadamiineae comprising Brabejum, Macadamia and Panopsis, and, independently, for the crown group of the subtribe Gevuininae comprising Gevnina Molina, Euplassa and Kermadecia Brongn. \& Gris (Fig. 3a).

Within the tribe Macadamieae, the vasicentric tracheids found in Malagasia (InsideWood 2004-onwards), Euplassa (Mennega 1966, Detienne \& Jacquet 1983), Panopsis (Mennega 1966), Macadamia (Chattaway 1948) and in Brabejum. Apparently, the gain of these tracheary elements is characteristic for the subtribe Macadamiineae (Fig. 3b). As for other Proteaceae, this feature has been reported in the genera of all there subfamilies, i.e. in Persoonia, Dilobeia, Faurea, Floydia L.A.S. Johnson \& B.G. Briggs, Hakea Schrad. \& J.C. Wendl., Stenocarpus, Xylomelum Sm., Roupala Aubl., and Knightia (Chattaway 1948, Metcalfe \& Chalk 1950, Mennega 1966, Detienne \& Jacquet 1983, Patel 1992, InsideWood 2004 onwards). No large-scale patterns in evolution of this trait were revealed.

Brabejum is distinctive from Macadamia and Panopsis (Mennega 1996, InsideWood 2004-onwards) in the thickness of libriform fiber walls as well as in the abundance and distribution of axial parenchyma. Unlike its closely related genera having axial parenchyma mostly in wide bands commonly arranged into reticular pattern, Brabejum has mostly unilaterally paratracheal axial parenchyma, occasionally with tangential lines and narrow bands in irregular arrangement. More abundant axial parenchyma in Macadamia and Panopsis, naturally distributed in regions with warmer climates than Brabejum (Queensland and The Guianas vs Western Cape, respectively) is seemingly consistent with the global tendency to increase of amount of axial parenchyma in wood in the regions with higher mean annual temperature (Morris et al. 2016).

High intrusiveness of libriform fibers found in Macadamia integrifolia $(\mathrm{F} / \mathrm{V}=3.98)$ is noteworthy: this species shows on of the highest $\mathrm{F} / \mathrm{V}$ ratio (3.98) reported within Proteaceae to date. This family is considered by Carlquist (2001) as one of the groups (together with Bignoniaceae Juss., Boraginaceae Juss., Malvaceae Juss., Moraceae Gaudich., Santalaceae R. Br., Scrophulariaceae Juss., Solanaceae Juss., Ulmaceae Mirb., Urticaceae Juss., and Verbenaceae J. St.-Hil.) with exceptional elongation of libriform fibers. The available data on lengths of vessel members and imperforate elements in wood (Bailey \& Tupper 1918, Mennega 1966, Lanyon 1979, Patel 1982) show, however, that the F/V ratio in most Proteaceae does not exceed 3.
Greater intrusiveness has been reported (Bailey \& Tupper 1918, Mennega 1966) only in Roupala montana Aubl. (F/V = 3.66), Banksia verticillata $\mathrm{R}$. Br. $(\mathrm{F} / \mathrm{V}=3.75)$, Grevillea robusta A. Cunn. ex R. Br. (F/V=4.0) and Hakea leucoptera R. Br. (F/ $\mathrm{V}=5.0$ ). More comprehensive data are required to clarify the evolutionary and/or ecological patterns of variation of this interesting trait within Proteaceae.

\section{ACKNOW LEDGEMENTS}

The authors thank the University of Johannesburg, the National Research Foundation of South Africa (grant No. 109531 for second author), the Komarov Botanical Institute of the Russian Academy of Sciences (institutional research project No. AAAA-A17-117051810115-1), and the Russian Foundation for Basic Research (grant No. 19-04-00714) for financial support, and the CapeNature for the collecting permit. We thank Mr. Mashudu Nndanduleni (Kirstenbosch National Botanical Garden) for his assistance in collecting the sample of Brabejum, and Mrs. Valentina Belkine for her kind permission to collect the wood of Macadamia in her property. The SEM observations have been carried out by scanning electron microscope TESCAN at the central analytical facility (called Spectrum) of the University of Johannesburg.

\section{LITERAT URE CITED}

Bailey, I.W. \& W.W. Tupper 1918. Size variation in tracheary cells. I. A comparison between the secondary xylems of vascular cryptogams, gymnosperms, and angiosperms. Proceedings of the American Academy of Arts and Sciences 54:149-204.

Carlquist, S. 2001. Comparative wood anatomy. Systematic, ecological, and evolutionary aspects of dicotyledon wood, 2nd ed. Springer-Verlag, Berlin, Heidelberg, 449 pp.

Chattaway, M.M. 1948. The wood anatomy of the Proteaceae. Australian Journal of Biological Sciences 1(3):279-302.

Crous, C.J., S.M. Jacobs \& K.J. Esler 2012. Wood anatomical traits as a measure of plant responses to water availability: invasive Acacia mearnsii De Wild. compared with native tree species in fynbos riparian ecotones, South Africa. Trees 26:1527-1536.

Detienne, P. \& P. Jacquet 1983. Atlas d'identification des bois de l'Amazonie et des regions voiseines. Centre Technique Forestier Tropical, Nogent s/Marne, 640 pp. (cited by InsideWood, 2004).

George, A.S. \& B.P.M. Hyland 1995. Orites. In: Flora of Australia, vol. 16 (P. McCarthy, ed.), pp. 346-352. CSIRO Australia, Melbourne.

IAWA Committee 1989. IAWA list of microscopic features for hardwood identification. IAWA Bulletin 10:221-331.

InsideWood (2004-onwards) InsideWood database. Available at http://insidewood.lib. ncsu.edu/. Last accessed 10.04.2019.

Jansen, S., B. Choat, S. Vinckier, F. Lens, P. Schols \& E. Smets 2004. Intervascular pit membranes with a torus in the wood of Ulmus (Ulmaceae) and related genera. New Phytologist 163:51-59.

Johansen, D.A. 1940. Plant microtechnique. McGraw-Hill, New York, 523 pp.

Kribs, D.A. 1968. Commercial foreign woods on the American market. Dover Publications, New York, 233 pp. 
Lanyon, J.W. 1979. The wood anatomy of three Proteaceous timbers Placospermum coriaceum, Dilobeia thouarsii and Garnieria spathulaefolia. IAWA Bulletin 2-3:27-33.

Mast, A.R., C.L. Willis, E.H. Jones, K.M. Downs \& P.H. Weston 2008. A smaller Macadamia from a more vagile tribe: inference of phylogenetic relationships, divergence times, and diaspore evolution in Macadamia and relatives (tribe Macadamieae; Proteaceae). American Journal of Botany 95(7):843-870.

Maddison, W.P., D.R. Maddison 2011. Mesquite: a modular system for evolutionary analysis. Version 2.75 http:// mesquiteproject.org.

Mennega, A.M.W. 1966. Wood anatomy of the genus Euplassa and its relation to other Proteaceae of the Guianas and Brazil. Acta Botanica Neerlandica 15:117-129.

Metcalfe, C.R. \& L. Chalk 1950. Anatomy of the Dicotyledons, vols 1-2. Clarendon Press, Oxford, 1500 pp.

Morris, H., L. Plavcová, S. Jansen, P. Cvecko, E. Fichtler, M.A.F. Gillingham, H.I. Martínez-Cabrera, D.J. McGlinn, E. Wheeler, J.M. Zheng \& K. Ziemińska 2016. A global analysis of parenchyma tissue fractions in secondary $\mathrm{xy}-$ lem of seed plants. New Phytologist 209:1553-1565.

Mucina, L. \& M.C. Rutherford (eds) 2006. The vegetation of South Africa, Lesotho and Swaziland. Strelitzia 19,
South African National Biodiversity Institute, Pretoria, 600 pp.

Patel, R.N. 1992. Wood anatomy of the dicotyledons indigenous to New Zealand. 22. Proteaceae. New Zealand Journal of Botany 30(4): 415-428.

Prance, G.T., V. Plana, K.S. Edwards \& R.T. Pennington 2007. Proteaceae. In: Flora Neotropica Monograph, vol. 100, pp. 1-218, NewYork Botanical Garden Press, NewYork.

Sosef, M.S.M., L.T. Hong \& S. Prawirohatmodjo (eds) 1998. Timber trees: Lesser-known timbers. Plant Resources of South-East Asia 5(3): 1-859 (Backhuys Publishers, Leiden).

Tortorelli, L.A. 1956. Maderas y bosques argentinoas. Editorial Acme, Buenos Aires, 515 pp.

Weston, P.H. 2007. Proteaceae. In: The Families and Genera of Vascular Plants. IX. Flowering Plants - Eudicots, (K. Kubitzki, ed.), pp. 364-404, Springer-Verlag, Berlin.

Weston, P.H. \& N.P. Barker 2006. A new suprageneric classification of the Proteaceae, with an annotated checklist of genera. Telopea 11(3):314-344. 